\title{
CRYPTOCURRENCIES, COVID-19 PANDEMIC AND THE FINANCIAL BUBBLES: THE CASE OF TOP FIVE DIGITAL ASSETS
}

Onur ÖZDEMIR ${ }^{1}$

Citation/@: Özdemir O. (2021). Cryptocurrencies, COVID-19 pandemic and the financial bubbles: the case of top five digital assets. Hitit Journal of Social Sciences, 14(1), 110-123. doi:10.17218/hititsbd.881250

Abstract: This study explores the bubble behavior in the prices of top five cryptocurrencies (i.e., Bitcoin, Ethereum, Ripple, Stellar, and Tether) using daily data of the closing level at the COVID-19 pandemic, covering the period from January 2, 2020 to January 2, 2021. The testing procedure of the bubble behavior in selected cryptocurrency prices is investigated by two methodologies, which are rarely applied in the relevant literature. Those covers the test statistics originated by the Supremum Augmented Dickey-Fuller (SADF) (Phillips et al., 2011) and Generalized Supremum Augmented DickeyFuller (GSADF) (Phillips et al., 2015) to define several bubble periods. The empirical results emphasize that bubble behavior is not a diverse and stable feature of Bitcoin, Ethereum, Ripple, and Stellar prices, except the Tether prices, which point out the emergence of a potential crisis in the digital assets market through an increasing degree of financial instability.

Keywords: Cryptocurrencies, Bubble Behavior, COVID-19, Financial Instability, Recursive Right-Tailed Tests

\section{Kripto Paralar, Covid-19 Pandemisi ve Finansal Balonlar: İlk Beş Dijital Varlık Örneği}

Atıf/@: Özdemir O. (2021). Kripto paralar, covid-19 pandemisi ve finansal balonlar: ilk beş dijital varlık örneği. Hitit Sosyal Bilimler Dergisi, 14(1), 110-123. doi: 10.17218/hititsbd.881250

Özet: Bu çalışma, 2 Ocak 2020 ve 2 Ocak 2021 arasındaki dönemi kapsayan COVID-19 pandemisindeki kapanış seviyesinin günlük verilerini kullanarak ilk beş kripto para biriminin (Bitcoin, Ethereum, Ripple, Stellar ve Tether) fiyatlarındaki balon davranışını araştırmaktadır. Seçilen kripto para birimlerinin fiyatlarındaki balon davranışını test etmek için kullanılan teknik mevcut literatürde az uygulanan iki farklı yöntem ile araştırılmaktadır. Bu yöntemler birden çok balon dönemini belirlemek için Eküs Genişletilmiş Dickey-Fuller (Supremum Augmented Dickey-Fuller-SADF) (Phillips et al., 2011) ve Genelleştirilmiş Eküs Genişletilmiş Dickey-Fuller (Generalized Supremum Augmented Dickey-Fuller-GSADF) (Phillips et al., 2015) tarafindan oluşturulan test istatistiklerinin kapsamaktadır. Elde edilen ampirik sonuçlar artan finansal istikrarsızlık nedeniyle Tether fiyatları dışında dijital varlık piyasasında potansiyel bir krizin ortaya çıktığını Bitcoin, Ethereum, Ripple ve Stellar fiyatlarında tekrar eden ve ortak bir balon davranışı çerçevesinde ortaya koymaktadır.

Anahtar Kelimeler: Kripto Paralar, Balon Davranışı, COVID-19, Finansal İstikrarsızlık, Özyinelemeli SağKuyruk Testleri

\section{INTRODUCTION}

Cryptocurrencies have become popular digital assets from the beginning of 2014 even though they have no intrinsic value and they do not offer any dividends or a specific amount of return. In particular, many investors still consider that those assets are the breakpoint for the time of

Research Article

Submitted: 16.2.2021

Accepted: 19.6.2021

1 Asst. Prof. Dr., Istanbul Gelisim University, Faculty of Economics, Administrative and Social Sciences, Department of International Trade and Finance (English), Istanbul, Turkey. onozdemir@gelisim.edu.tr, http://orcid.org/0000-0002-38040062 
downturns in the economic environment. The year 2020 indicates such a time when the Coronavirus (COVID-19 hereafter) outbreak has rapidly spread all over the world and has severely affected the behaviors of investors to avoid themselves from the negative consequences of the lockdowns and thereby the loss of production. Therefore, the interest of financial investors in such digital assets at the COVID-19 pandemic has been ever increased all over the world. For instance, the demand for those assets has skyrocketed in amounts over the one-year period which began at the outset of January 2020. In that vein, it poses some potential causes of economic problems since it conveys to the emergence of financial bubbles to burst in the future. The core reason for that bursting of bubbles depends on the fact that the digital assets still have no legal tender or official means of exchange (Geuder et al., 2019). Therefore, it leads to the occurrence of an increase in speculative behavior among investors. For instance, they may consider that buying digital assets along with their scarce amount in supply allows them to close out those assets in the future, which in turn may cause an increase in speculative motives and thereby the bursting of financial bubbles. A glance at the prices of some top digital assets such as Bitcoin, Ethereum, and Ripple for the period between January 2, 2020 and January 2, 2021 can reveal the evidence confirming this conclusion. The prices of Bitcoin and Ethereum increase to about USD 29,110 and USD 1,017 per coin in January 2021 may have come along the uprising anxiety of several financial analysts and private investors. This raises to question of whether the digital assets exhibit price behavior that is prompted by the renowned trends of financial bubbles in the cryptocurrency market. While the relevant literature on digital assets has become rapidly a popular era for the analytical structure, the question of bubble behavior is still much less well documented, especially in the COVID-19 outbreak. In addition, most papers focused on some specific cryptocurrencies such as Bitcoin and Ethereum, which are relatively more famous among the investors, and thus they deal with particular channels of influence covering the price determinants, market sentiment, the bubble periods, the efficiency of those assets, and the informed digital assets trading (Ciaian et al., 2018; Corbet et al., 2018; Vidal-Tomás and Ibañes, 2018; Zhang et al., 2018).

The major contribution of this study to the relevant literature is composed of two channels. On the one hand, it imposes newly developed right-tailed unit root testing methods, namely the Supremum Augmented Dickey-Fuller (SADF) test and the Generalized Supremum Augmented Dickey-Fuller (GSADF) test, which are initiated by Phillips et al. (2011) and Phillips (2015). The major reason to use those methods depends on the fact that the recent literature mostly uses techniques which are not considered the explosive type of bubble behavior to cover the price variations in financial assets. However, the period after the COVID-19 pandemic shows a wide range of differences in asset prices where the bubble behaviors in such assets become a leading pattern of finance. Therefore, this paper discusses that kind of problem that may occur in asset markets by way of using above mentioned two methods for detecting and date-stamping financial bubbles. On the other hand, the second key feature of this paper is to reveal the bubble behavior could emerge mostly in the time of harsh economic downturns such as the COVID-19 outbreak. One of the main reasons for that bubble behavior could be occurred due to a slowdown of production and thereby the profit-loss of firms. Since the revenues become narrower in periods of economic downturns, most of the investors lead to increase their purchases towards the financial assets. Therefore, in those periods, the asset prices move away from their actual values and thus may exhibit an explosive bubble-type behavior.

In this paper, we use daily US\$ prices of the top five cryptocurrencies covering Bitcoin (BTC), Ethereum (ETH), Ripple (XRP), Stellar (XLM), and Tether (USDT) with a focus on identifying and analyzing bubble behavior for the period between January 2, 2020 and January 2, 2021. For this 
purpose, we use two distinct right-tailed testing methods, i.e., the Supremum Augmented DickeyFuller (SADF) test developed by Phillips et al. (2011; PWY hereafter) and the Generalized Supremum Augmented Dickey-Fuller (GSADF) test developed by Phillips et al. (2015; PSY hereafter). The distinguishing feature of those methods is to identify potential bubble periods through their emergence and termination dates. Especially the PSY methodology approaches that asset prices at the outset of financial bubbles show explosive behavior. By the way, the major reason to choose those selected five cryptocurrencies depends on the fact that each one exhibits a high degree of volatility in case of the demand-side effects and thereby an outstanding increase in their prices relative to the rest of the others.

The empirical findings show that there is an existence of bubble periods in selected top five prices which is emphasized by the PWY and PSY methods. In particular, the models identify not only one but several sub-periods of bubble behavior for those digital assets. The rest of the paper is organized as follows. Section 2 briefly summarizes the studies investigating the effect of COVID19 on the cryptocurrency market. Section 3 presents the data and empirical methodology. Section 4 lists the empirical findings. Section 5 concludes the paper with the evaluation of the findings.

\section{LITERATURE REVIEW}

The literature has paid critical attention by several researchers and financial analysts to an everincreasing degree of issuing digital assets in the context of their efficiency and effectiveness compared to other financial assets (Ceylan et al., 2018; Afşar, 2019; Hepkorucu and Genç, 2019; Mete et al., 2019). In particular, a bulk of studies have been done to explore the nature of the effects of the COVID-19 pandemic on selling and buying behaviors of financial investors, which have been rapidly increased in the Coronavirus outbreak (Keçeci, 2020; Polat and Tuncel, 2020; Şahin, 2020). According to Conlon and McGee (2020), Bitcoin, for instance, may not be a safe haven for investors to get rid of the detrimental effects of financial bubbles and thus may exhibit a similar pattern with the S\&P 500. The major way that leads to that kind of instance can be implemented by looking at the composite analysis in which the downside risk of inclusion of Bitcoin into the portfolio may increase significantly. Therefore, it corresponds to the case that many investors may not move towards buying Bitcoin since they do not feel comfortable in case of the belief for its protective role at the outset of financial turbulence. Corbet et al. (2020) argue that there are short-run and dynamic correlations between Bitcoin and Chinese stock markets following the period of the COVID-19 outbreak. Conlon et al. (2020) focus on the hedging role of the top three cryptocurrencies (i.e., Bitcoin, Ethereum, and Tether) to examine their protective feature from the financial bubbles. The empirical findings show that Bitcoin and Ethereum may not be safe heaven when they are included in the portfolios by way of increasing downside risk, whereas Tether, which pegs to the US Dollar, serves as a hedge at the outset of the COVID-19 pandemic. In addition, Mnif et al. (2020) explore the cryptocurrency market efficiency by the comparison of before and after the COVID-19 pandemic and find that it has a positive impact on the market efficiency. James et al. (2019) introduce new methods for investigating the erratic behavior of time series to assess the effect of COVID-19 on digital asset market dynamics. The empirical findings show that the individual cryptocurrencies behave irregularly in their erratic behavior, which is relevant in consistently volatile markets, and are also more affected during the COVID-19 market crisis. There are also other studies which of those are dealt with the prices of different digital assets and currencies to investigate the herding behavior, co-explosivity, and cojumping behavior of those asset returns (Bouri et al., 2019; 2020). Some others such as the work of Kristoufek (2020) imply that gold should be considered as a safe haven in contrast to Bitcoin. Lahmiri and Bekiros (2020) concentrate on the comparison between the cryptocurrencies and the 
international stock market for the period of the COVID-19 pandemic. According to their empirical outcomes, the Coronavirus pandemic has much powerful on the cryptocurrency market than the international stock market in which the former is more unstable and irregular in case of their returns. Goodell and Goutte (2020) focus on the relationship between the prices of Bitcoin and daily data of Coronavirus deaths. They find that the prices of Bitcoin were pushed up in a positive trend by the COVID-19 pandemic following the date of April 5, 2020. Finally, Yarovaya et al. (2020) analyze the herding behavior in the cryptocurrency market and find that the statistical significance of COVID-19 in terms of its positive effect on herding in the cryptocurrency market is not relevant. The next section lists the data that we use in the empirical analysis and also summarizes the details of empirical methodology.

\section{DATA AND METHODOLOGY}

\subsection{Data}

This paper investigates the relationship between the prices of the top five cryptocurrencies and the COVID-19 pandemic. Our dataset contains daily closing prices of Bitcoin (BTC), Ethereum (ETH), Ripple (XRP), Stellar (XLM), and Tether (USDT), $P_{t}$, denominated in U.S. dollars during the period from January 2, 2020 until January 2, 2021 as extracted from Coindesk.com. Since the cryptocurrencies are traded in continuum moments, the data is extracted for all available days and corresponds to a total of $T=367$ days for selected top five cryptocurrencies. Also, the empirical outcomes are obtained by the statistical software EViews 10.

The descriptive statistics are represented in Table 1. As the maximum and minimum values show that the prices of those assets exhibit large changes in the sample throughout the determined range of period, which refers to our initial question of bubble behavior in the COVID-19 outbreak. In particular, the closing prices of the selected five cryptocurrencies are positively skewed. Besides, their distribution of returns is not unique such as leptokurtic and mesokurtic.

Table 1. Summary statistics

\begin{tabular}{lrrrrrrr}
\hline & Observation & Mean & $\begin{array}{r}\text { Standard } \\
\text { Deviation }\end{array}$ & Minimum & Maximum & Skewness & Kurtosis \\
\hline Bitcoin(BTC) & 367 & 11117.1 & 4392.5 & 4944.7 & 29333.6 & 1.836 & 6.477 \\
\hline Ethereum (ETH) & 367 & 308.8 & 145.5 & 107.9 & 746.1 & 0.903 & 3.104 \\
\hline Ripple(XRP) & 367 & 0.2583 & 0.1043 & 0.1386 & 0.6843 & 2.382 & 8.202 \\
\hline Stellar (XLM) & 367 & 0.0824 & 0.0345 & 0.0344 & 0.1998 & 1.599 & 5.378 \\
\hline Tether (USDT) & 367 & 1.0006 & 0.0014 & 0.9968 & 1.0140 & 2.464 & 25.54 \\
\hline
\end{tabular}

\subsection{Empirical Methodology}

The first issue in the empirical context depends on the examination of a right-tailed version of the traditional Augmented Dickey-Fuller test with the parameter $\delta$, which is developed by Phillips et al. (2011). The test statistics of PWY method is based on the following stationary analysis of explosive root:

$H_{0}: \delta=1$

$H_{a}: \delta \neq 1$

The rejection of the null hypothesis $\left(\mathrm{H}_{0}\right)$ refers that there is an explosive root in the series. Therefore, it indirectly implies that the alternative hypothesis $\left(\mathrm{H}_{\mathrm{a}}\right)$ denotes the case of series which have explosive roots. In that vein, the rejection of $\mathrm{H}_{0}$ points out that the financial bubbles are statistically significant across the selected series. There are two types of statistics in which the PWY method refers to the analysis. The first one is so-called the supremum ADF (i.e., SADF) and 
the second is called the generalized supremum ADF (i.e., GSADF). The theoretical basis of those statistics can be represented as in Eqs. (1) and (2), respectively:

$$
\begin{aligned}
& \operatorname{SADF}\left(r_{0}\right)=\sup _{r_{2} \in\left[r_{0}, 1\right]}\left\{A D F_{0}^{r_{2}}\right\} \\
& \operatorname{GSADF}\left(r_{0}\right)=\sup _{r_{2} \in\left[r_{0}, 1\right] ; r_{1} \in\left[0, r_{2}-r_{1}\right]}\left\{A D F_{r_{1}}^{r_{2}}\right\}
\end{aligned}
$$

where $r_{1}, r_{2} \in[0,1]$ capture the series of subsamples. Compared to the SADF test statistics, the GSADF test statistics are more efficient and effective in terms of the robustness of their results since they provide more flexibility in window width and thereby have more fractions of the overall sample.

To find the potential existence of the explosive root in the series, one should also further extend the presence of one or multiple bubble periods. Therefore, the PSY method produced by Phillips et al. (2015) represents a double recursive method based on the backward supremum ADF (i.e., BSADF). Equation (3) denotes the theoretical representation of the BSADF method:

$$
\operatorname{BSADF}_{\left(r_{2}\right)}\left(r_{0}\right)=\sup _{r_{1} \in\left[0, r_{2}-r_{0}\right]}\left\{A D F_{r_{1}}^{r_{2}}\right\}
$$

Indeed, the last procedure is composed of several determinants given from the initial two methods, namely the SADF and the GSADF. According to the BSADF testing procedure, the series should be divided into two periods when the bubbles start in $\hat{r}_{i, b}$ and end in $\hat{r}_{i, e}$. Eqs. (4) and (5) respectively presents them in the theoretical context as follows:

$$
\begin{aligned}
& \hat{r}_{i, b}=\inf _{r_{2} \epsilon\left[r_{0}, 1\right]}\left\{r_{2}: B S A D F_{r_{2}}\left(r_{0}\right)>s c v_{r_{2}}^{\alpha_{T}}\right\} \\
& \hat{r}_{i, e}=\inf _{r_{2} \epsilon\left[\hat{r}_{i, b}+\frac{\gamma \log (T)}{T}, 1\right]}\left\{r_{2}: B S A D F_{r_{2}}\left(r_{0}\right)<s c v_{r_{2}}^{\alpha_{T}}\right\}
\end{aligned}
$$

To detect the possible occurrence of multiple bubbles, the recursive rolling window is also extended through the studies of Phillips and Shi $(2018,2020)$. Each observation in the sample ranges between interval $\left[r_{0}, 1\right]$ where $r_{0}=0.01+1.8 / \sqrt{T}$.

The regression analysis covers the estimates for the null hypothesis of $\rho=0$, which is represented in Eq. (6):

$$
\Delta y_{t}=\mu+\delta y_{t-1}+\sum_{i=1}^{p} \varnothing_{i} \Delta y_{t-i}+\varepsilon_{t}
$$

In consideration of Equation (6), the multiple bubbles can be used to determine the period by way of two dates matching as the exuberance date and the collapse date. While the former implies that the test statistics provided by the PSY method are initially higher than its critical value at the point where the first episode ends, the latter states that the supremum test statistics drop below the essential value to the point where the second episode is concluded. In that sense, the episode can be assumed as unitary for a selected sample that arises from $r_{e}$ and $r_{f}$. Eqs. (7) and (8) are used to determine the estimated periods and termination dates:

$$
\begin{aligned}
& \hat{r}_{e}=\inf _{r \in\left[r_{0}, 1\right]}\left\{r: P S Y_{r}\left(r_{0}\right)>c v_{r}\left(\beta_{T}\right)\right\} \\
& \hat{r}_{f}=\inf _{r \in\left[\hat{r}_{e}, 1\right]}\left\{r: P S Y_{r}\left(r_{0}\right)<c v_{r}\left(\beta_{T}\right)\right\}
\end{aligned}
$$

where $c v_{r}\left(\beta_{T}\right)$ denotes the quantile of the distribution of $\operatorname{PSY}_{r}\left(r_{0}\right)$.

\section{EMPIRICAL FINDINGS}

Table 2 reports the test statistics for the SADF and GSADF procedures for the prices of selected top five cryptocurrencies with the critical values produced by the implementation of Monte Carlo simulation in EViews 10 package. In the context of the theoretical implications of Phillips et al. 
(2015), the initial window width is calculated as $r_{0}=0.01+1.8 / \sqrt{367} \approx 0.103$, which yields 0.103 * $367 \approx 38$. In other words, this estimation output implies that the initial window width has approximately 38 observations. In consideration of the given initial window width, the right-tailed unit root test statistics show that the null hypothesis of no explosive unit in the series is rejected at the \%1 significance level for BTC, ETH, XRP, and XLM except the USDT in favor of the alternative hypothesis, which yields that the series have at least one explosive unit. These results are statistically valid for both SADF and GSADF testing procedures. In addition, the estimates also imply that the bubble behavior in at least one period of the changes in the prices of four selected cryptocurrencies can be assumed as prevailing at the COVID-19 pandemic. Therefore, the subperiods of the explosive bubble behavior should be taken for granted in terms of the prices of those selected cryptocurrencies.

The empirical outputs representing in Figs. 1-5 show the results from the backward SADF sequences and their corresponding 95\% critical value sequences on the left axis and the closing prices on the right axis. On the one hand, Figs. 1-4 imply that both the SADF and GSADF tests have to contain subperiods with bubble behavior. In other words, starting from January 2, 2020 until January 2, 2021, the series for Bitcoin (BTC), Ethereum (ETH), Ripple (XRP), and Stellar (XLM) indicate to the case that backward SADF sequences exceed $95 \%$ critical value sequences, representing the occurrence of at least one explosive bubble in the series. These representations are also validated with the given test statistics of SADF and GSADF in Table 2 (Conlon and McGee, 2020). However, the last digital asset which is Tether (USDT) shows no bubble behavior in the COVID-19 outbreak. Therefore, besides the prices of the former four cryptocurrencies, the Tether (USDT) can be considered as one of the last resorts that the financial investors can avoid making a loss in transactions of digital assets. Also, while the other digital assets may not be safe heaven due to their increasing level of downside risk into the portfolios, the Tether is pegged to the US Dollar and thus serves as a hedge at the COVID-19 pandemic. This is also substantially coherent with the empirical findings of Conlon et al. (2020). The current results are also contradicted with the empirical findings of Mnif et al. (2020) in which they argue that an increase in cryptocurrency markets raises the market efficiency but there is an increase in volatility spillover in the digital asset markets. In particular, a great majority of studies are found to indicate suck kind of behaviors of information inefficiency of primary importance in consideration of volatility spillovers in the cryptocurrency market (Urquhart and Hudson, 2013; Ito et al., 2014; Urquhart and McGroarty, 2016; Hu et al., 2019; Kyrazis, 2019; Le Tran and Leirvik, 2020). This is what James et al. (2019) find that the individual cryptocurrencies behave irregularly in their erratic behavior along with consistent volatile markets, and more affected during the COVID-19 market crisis. Related to that those evidence of market inefficiency, other studies provide reinforcement to the current findings and show that cryptocurrencies are mutually correlated in their feedback positions indicating by volatility spillover, volatility co-movement, lead/lag effect, calendar effect, and day-of-the-week effect (Aharon and Qadan, 2019; Omane-Adjepong and Alagidede, 2019; Katsiampa et al., 2019; Palamalai and Maity, 2019; Sifat et al., 2019; Yousaf and Ali, 2020; Corbet et al., 2021; Ghorbel and Jeribi, 2021; Kinateder and Papavassiliou, 2021). The current empirical results are also significant to understand the herding behavior, co-explosivity, and co-jumping behavior in digital asset returns (Bouri et al., 2019; 2020). 
Table 2. SADF and GSADF test statistics (Prices of cryptocurrencies)

\begin{tabular}{|c|c|c|c|c|}
\hline & \multirow[t]{2}{*}{ Test Statistics } & \multicolumn{2}{|c|}{ Critical Values } & \multirow[b]{2}{*}{$99 \%$} \\
\hline & & $90 \%$ & $95 \%$ & \\
\hline \multicolumn{5}{|c|}{ Bitcoin (BTC) } \\
\hline SADF & $2.5344^{* * *}$ & 0.3669 & 0.5959 & 1.1394 \\
\hline GSADF & $2.5488 * * *$ & 1.0647 & 1.2526 & 1.8548 \\
\hline \multicolumn{5}{|c|}{ Ethereum (ETH) } \\
\hline SADF & $1.2054^{* * *}$ & 0.3669 & 0.5959 & 1.1394 \\
\hline GSADF & $2.1824^{* * *}$ & 1.0647 & 1.2526 & 1.8548 \\
\hline \multicolumn{5}{|c|}{ Ripple (XRP) } \\
\hline SADF & $5.5497^{* * *}$ & 0.3669 & 0.5959 & 1.1394 \\
\hline GSADF & $9.3235^{* * *}$ & 1.0647 & 1.2526 & 1.8548 \\
\hline \multicolumn{5}{|c|}{ Stellar (XLM) } \\
\hline SADF & $1.3124^{* * *}$ & 0.3669 & 0.5959 & 1.1394 \\
\hline GSADF & $7.5767 * * *$ & 1.0647 & 1.2526 & 1.8548 \\
\hline \multicolumn{5}{|c|}{ Tether (USDT) } \\
\hline SADF & -2.7499 & 0.3669 & 0.5959 & 1.1394 \\
\hline GSADF & -2.3176 & 1.0647 & 1.2526 & 1.8548 \\
\hline
\end{tabular}

Notes: The critical values for SADF and GSADF test statistics are obtained by Monte Carlo simulation. The initial window size is 38 . The lag length selection criterion for unit root testing is determined as the Akaike Information Criterion (AIC). The constant and trend is included in the test equation. The sample size is 367 and the replications are 1000. The sample period is from January 2, 2020 and January 2, 2021. *** means that the test statistics are significant at \%99 confidence level.

All in all, the empirical findings based on the SADF and GSADF test statistics get in harmony with the recent literature in which the studies assume that the positive bubbles are likely to emerge throughout time. In that vein, the distinctive characteristic of this paper is to show that the excess demand for some popular digital assets might have the potential to burst in the COVID19 pandemic for the period between January 2, 2020 and January 2, 2021, which also imply that the bubbles are likely to burst in the following period.

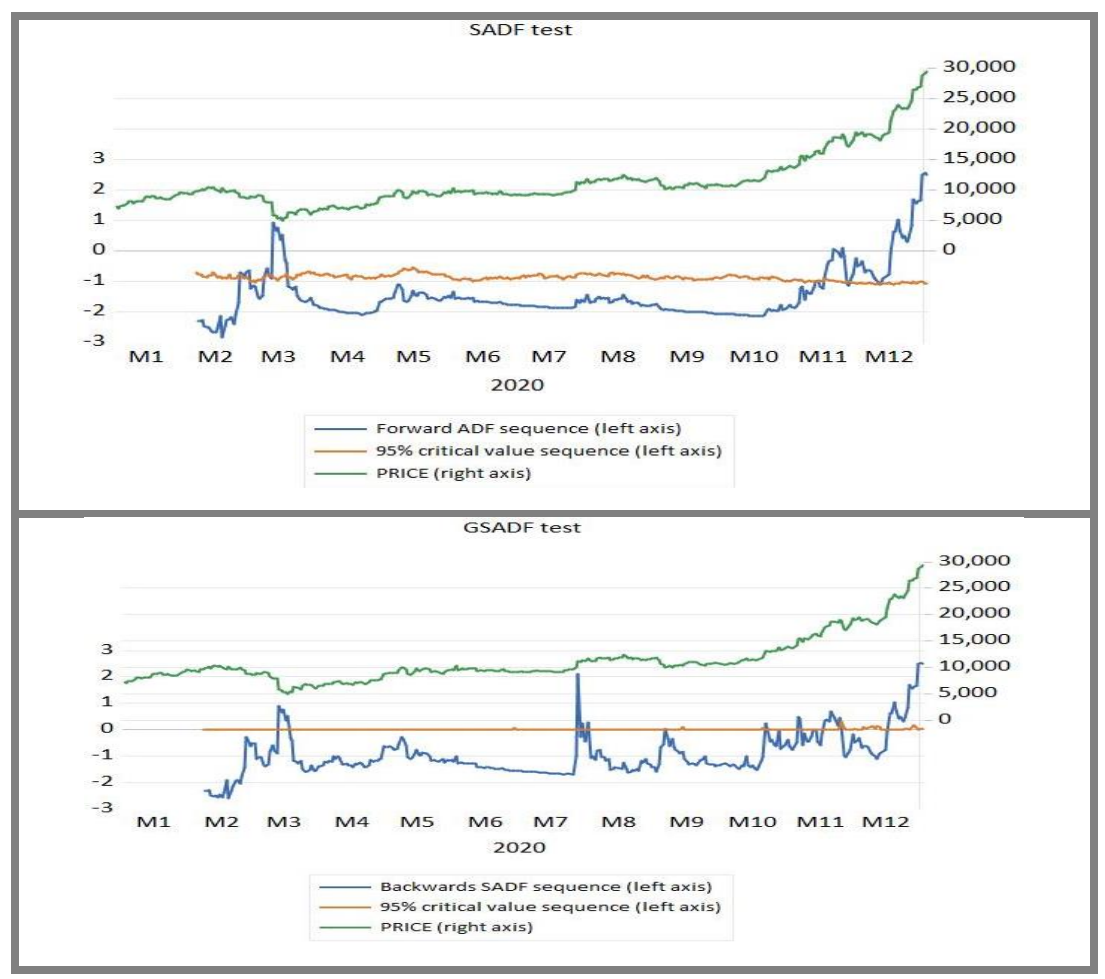

Figure 1. The SADF and GSADF test results of BTC 


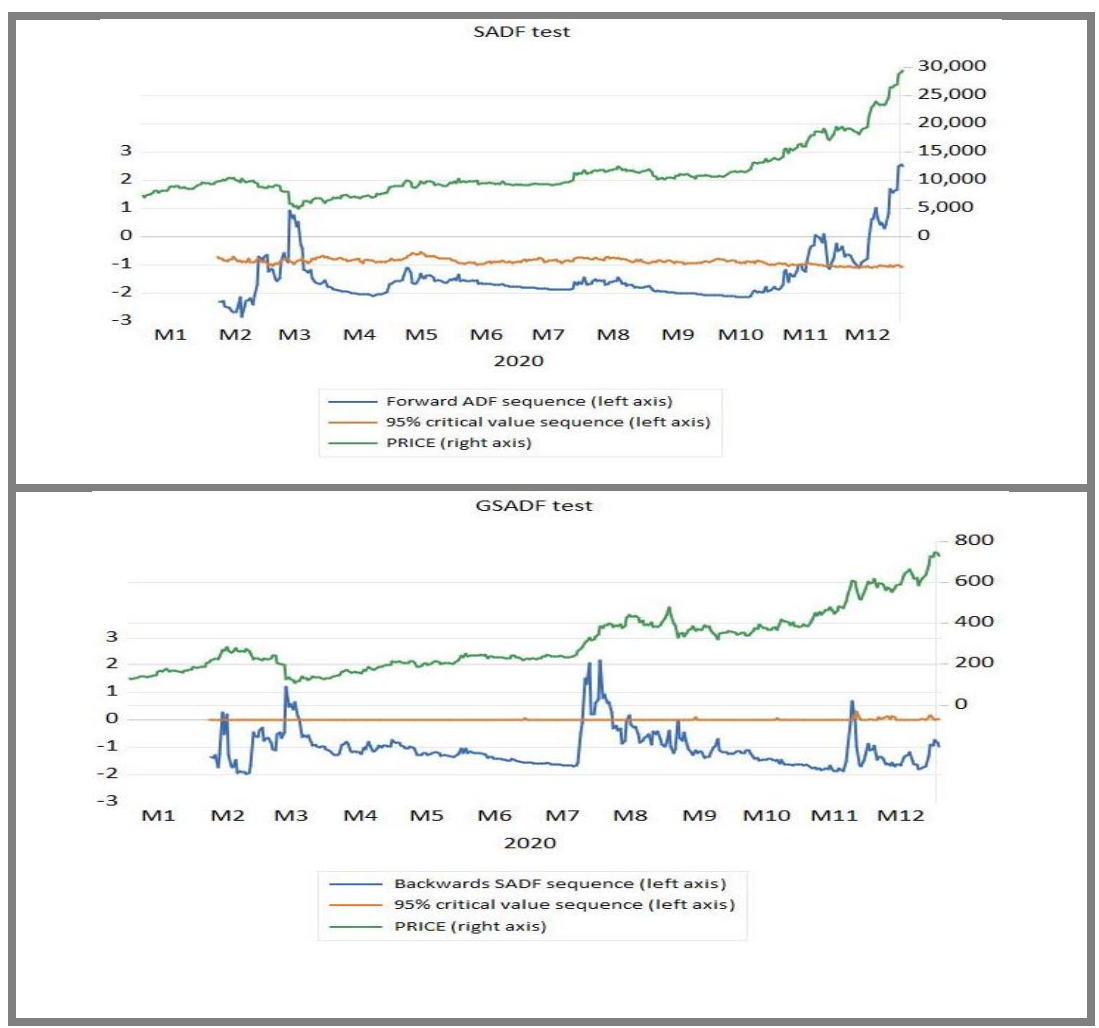

Figure 2. The SADF and GSADF test results of ETH

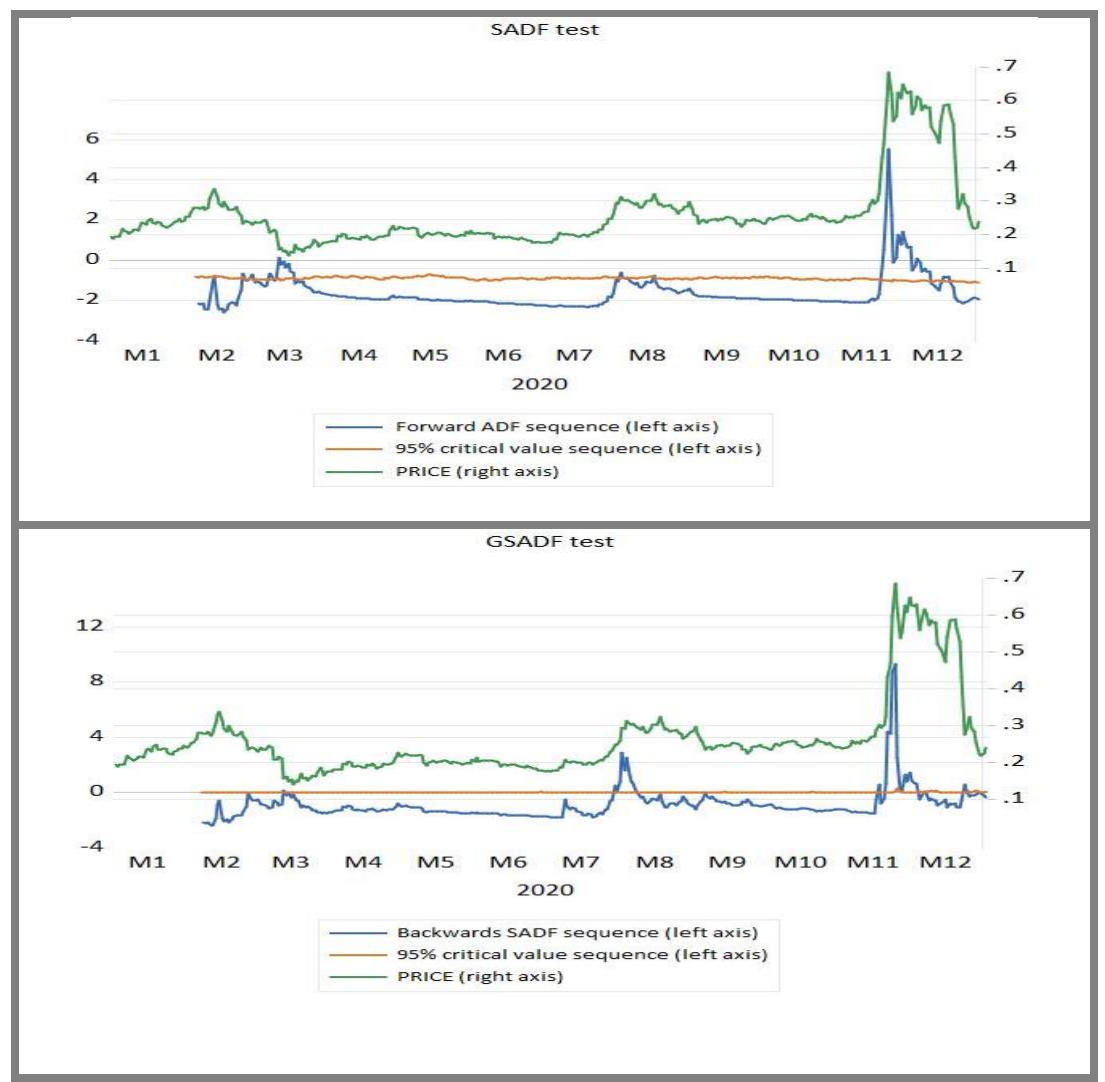

Figure 3. The SADF and GSADF test results of XRP 


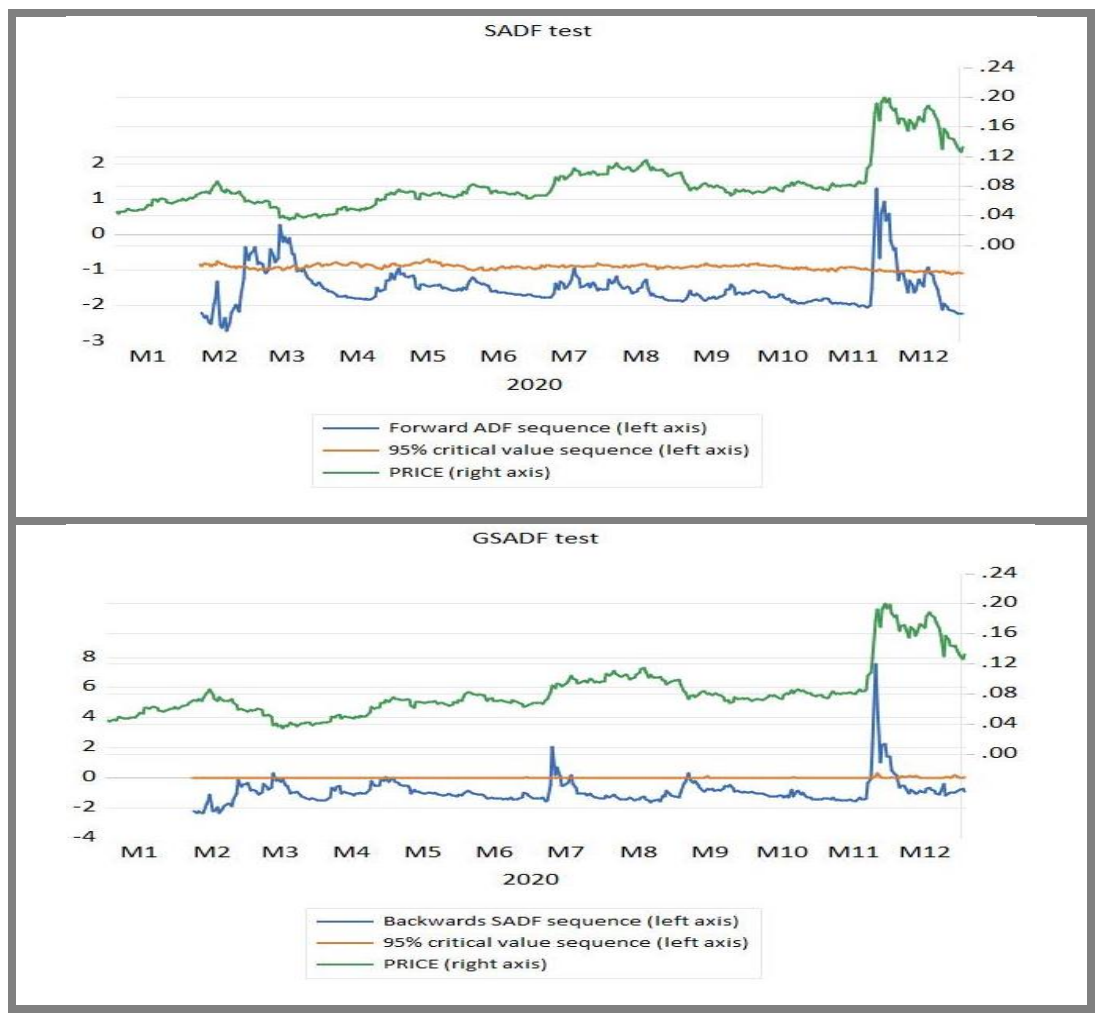

Figure 4. The SADF and GSADF test results of XLM

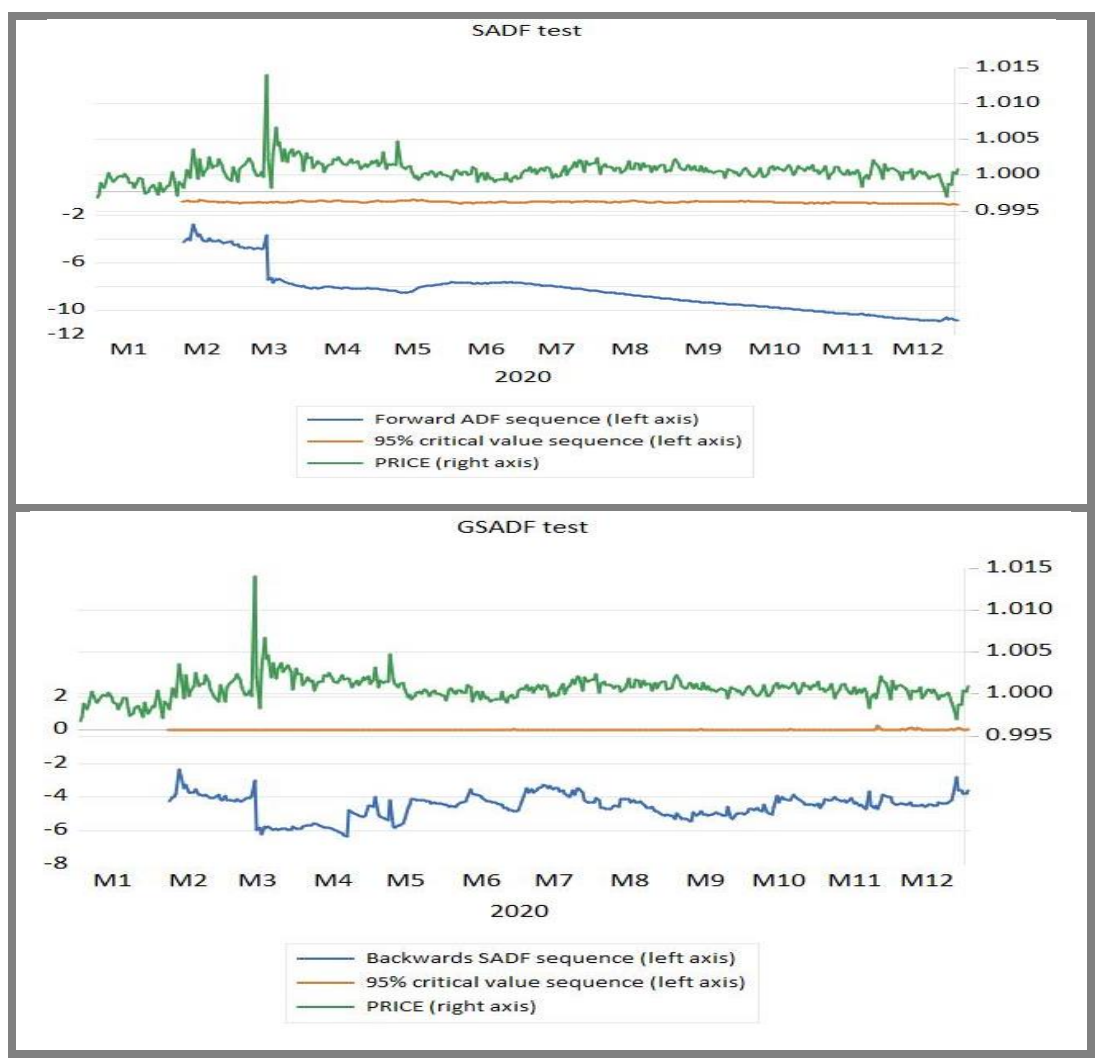

Figure 5. The SADF and GSADF test results of USDT 


\section{CONCLUSION}

With this study, we address the question of selected digital assets as an explosive bubble. In consideration of the estimates from the recursive right-tailed tests, namely the SADF and GSADF, we thereby confirm the existence of frequent bubble periods ranging between January 2, 2020 and January 2, 2021 for four different cryptocurrencies (i.e., Bitcoin, Ethereum, Ripple, and Stellar). However, the same conclusion cannot be made for Tether where the potential of explosiveness is not prevalent. One of the major reasons for this result may cause from the pegged of Tether to the US Dollar. Following those results in terms of an explosive bubble, this study contradicts with the rational bubble view in the existing literature; and therefore, it leads further studies to be done for investigation of reasons and determinants that may contribute to explain the price behaviors of Bitcoin, Ethereum, Ripple, and Stellar. Given the global pandemic for the world system, the economic issues such as lockdowns, surging unemployment rates, lowering the level of industrial production, and an increasing degree of speculative motives through Ponzi-type finance may have significantly altered the price behaviors of digital assets. To make deeper analyses on that issue, further studies should be needed in the context of different methods. In particular, to extend the outputs of current techniques that the study uses, it may be benefited from the other new methods such as GARCH models and the wavelet analyses.

Peer-review: Externally peer-reviewed.

Conflict of Interest: The author declare that there is no conflict of interest.

Funding: The author received no financial support for the research, authorship and/or publication of this article.

Ethical Approval: This article does not contain any studies with human participants or animals performed by the author.

Author Contributions: Onur Özdemir (100\%)

\section{REFERENCES}

Afşar, M., Afşar, A., and Doğan, E. (2019). Döviz balonlarının tespitine yönelik bir analiz: Türkiye örneği. Erciyes Üniversitesi İktisadi ve İdari Bilimler Fakültesi Dergisi, 54, 447-460. doi: 10.18070/erciyesiibd.461888

Aharon, D. Y., and Qadan, M. (2019). Bitcoin and the day-of-the-week effect. Finance Research Letters, 31. doi: 10.1016/j.frl.2018.12.004

Bouri, E., Shahzad, S. J. H., and Roubaud, D. (2019). Co-explosivity in the cryptocurrency market. Finance Research Letters, 29, 178-183. doi: 10.1016/j.frl.2018.07.005

Bouri, E., Gkillas, K., and Gupta, R. (2020). Trade uncertainties and the hedging abilities of Bitcoin. Economic Notes, 49(3), e12173. doi: 10.1111/ecno.12173

Ceylan, F., Ekinci, R., Tüzün, O., and Kahyaoğlu, H. (2018). Kripto para piyasasında balonların tespiti: Bitcoin ve Ethereum örneği. Business and Management Studies: An International Journal, 6(3), 263-274. doi: 10.15295/bmij.v6i3.355

Ciaian, P., Rajcaniova, M., and Kancs, A. (2018). Virtual relationships: short- and long-run evidence from Bitcoin and altcoin markets. Journal of International Financial Markets, Institutions and Money, 52, 173-195. doi: 10.1016/j.intfin.2017.11.001

Conlon, T., and McGee, R. J. (2020). Safe haven or risky hazard? Bitcoin during the COVID-19 bear market. Finance Research Letters, 35, 101607. doi: 10.1016/j.frl.2020.101607

Conlon, T., Corbet, S., and McGee, R. J. (2020). Are cryptocurrencies a safe have for equity markets? An international perspective from the COVID-19 pandemic. Research in International Business and Finance, 54, 101248. doi: 10.1016/j.ribaf.2020.101248 
Corbet, S., Lucey, B., and Yarovaya, L. (2018). Datestamping the Bitcoin and Ethereum bubbles. Finance Research Letters, 26, 81-88. doi: 10.1016/j.frl.2017.12.006

Corbet, S. Larkin, C., and Lucey, B. (2020). The contagion effects of the COVID-19 pandemic: evidence from gold and cryptocurrencies. Finance Research Letters, 35, 10155. doi: $10.1016 /$ j.frl.2020.101554

Corbet, S., Hou, Y., Hu, Y., Oxley, L., and Xu, D. (2021). Pandemic-related financial market volatility spillovers: evidence from the Chinese COVID-19 epicentre. International Review of Economics and Finance, 71, 55-81. doi: 10.1016/j.iref.2020.06.022

Geuder, J., Kinateder, H., and Wagner, N. F. (2019). Cryptocurrencies as financial bubbles: the case of Bitcoin. Finance Research Letters, 31, 179-184. doi: 10.1016/j.frl.2018.11.011

Ghorbel, A. and Jeribi, A. (2021). Investigating the relationship between volatilities of cryptocurrencies and other financial assets. Decisions in Economics and Finance, 449. doi: $10.1007 / \mathrm{s} 10203-020-00312-9$

Goodell, J. W., and Goutte, S. (2020). Co-movement of COVID-19 and Bitcoin: evidence from wavelet coherence analysis. Finance Research Letters, forthcoming. doi: $10.1016 /$ j.frl.2020.101625

Hepkorucu, A., and Genç, S. (2019). Kripto para değerleri için spekülatif fiyat balonlarının test edilmesi: Bitcoin üzerine bir uygulama. Veri Bilimi Dergisi, 2(1), 44-50.

Hu, Y., Valera, H. G. A., and Oxley, L. (2019). Market efficiency of the top market-cap cryptocurrencies: further evidence from a panel framework. Finance Research Letters, 31, 138-145. doi: 10.1016/j.frl.2019.04.012

Ito, M., Noda, A., and Wada, T. (2014). International stock market efficiency: a non-Bayesian timevarying model approach. Applied Economics, 46(23), 2744-2754. doi: $10.1080 / 00036846.2014 .909579$

James, N., Menzies, M., and Chan, J. (2019). Changes to the extreme and erratic behaviour of cryptocurrencies during COVID-19. Retrieved from: https://arxiv.org/abs/1912.06193

Katsiampa, P., Corbet, S., and Lucey, B. (2019). High frequency volatility co-movements in cryptocurrency markets. Journal of International Financial Markets, Institutions and Money, 62, 35-62. doi: 10.1016/j.intfin.2019.05.003

Keçeci, N. F. (2020). Dört büyük kriptoparanın piyasa riskinde COVID-19 pandemi etkisi. Journal of Research in Economics, Politics and Finance, 5, 206-224. doi: 10.30784/epfad.811219

Kinateder, H., and Papavassiliou, V. G. (2021). Calendar effects in Bitcoin returns and volatility. Finance Research Letters, 38, 101420. doi: 10.1016/j.frl.2019.101420

Kristoufek, L. (2020). Grandpa, grandpa, tell me the one about Bitcoin being a safe haven: evidence from the COVID-19 pandemics. Retrieved from: https://arxiv.org/abs/2004.00047

Kyrazis, N. A. (2019). A survey on efficiency and profitable trading opportunities in cryptocurrency markets. Journal of Risk and Financial Management, 12(2), 67. doi: 10.3390/jrfm 12020067

Le Tran, V. and Leirvik, T. (2020). Efficiency in markets of crypto-currencies. Finance Research Letters, 35, 101382. doi: 10.1016/j.frl.2019.101382

Lahmiri, S., and Bekiros, S. (2020). The impact of COVID-19 pandemic upon stability and sequential irregularity of equity and cryptocurrency markets. Chaos, Solitons \& Fractals, 138, 109936. doi: 10.1016/j.chaos.2020.109936 
Mete, S., Koy, A., and Ersoy, H. (2019). Kriptoparalarda fiyat balonu incelemesi. BDDK Bankaculık ve Finansal Piyasalar Dergisi, 13(1), 105-120.

Mnif, E., Jarboui, A., and Mouakhar, K. (2020). How the cryptocurrency market has performed during COVID-19? A multifractal analysis. Finance Research Letters, 36, (1016479), 1-14.

Omane-Adjepong, M., and Alagidede, I. P. (2019). Multiresolution analysis and spillovers of major cryptocurrency markets. Research in International Business and Finance, 49, 191-206. doi: $10.1016 /$ j.ribaf.2019.03.003

Palamalai, S., and Maity, B. (2019). Return and volatility spillover effects in leading cryptocurrencies. Global Economy Journal, 19(3), 1-20. doi: 10.1142/S2194565919500179

Phillips, P. C. B., and Shi, S-P. (2018). Financial bubble implosion and reverse regression. Econometric Theory, 34(4), 705-753. doi: 10.1017/S01266466617000202

Phillips, P. C. B., and Shi, S-P. (2020). Real time monitoring of asset markets: bubbles and crises. In: H. D. Vinod and C. R. Rao (Eds.), Handbook of statistics: financial, macro and micro econometrics using $R$, vol. 42, 61-80, Amsterdam: Elsevier.

Phillips, P. C. B., Wu, Y., and Yu, J. (2011). Explosive behavior in the 1990s Nasdaq: when did exuberance escalate asset values? International Economic Review, 52, 201-226. doi: $10.1111 / \mathrm{j} .1468-2354.2010 .00625 . \mathrm{x}$

Phillips, P. C. B., Shi, S-P., and Yu, J. (2015). Testing for multiple bubbles: historical episodes of exuberance and collapse in the S\&P 500. International Economic Review, 56, 1043-1078. doi: $10.1111 /$ iere. 12132

Polat, M., and Tuncel, F. B. (2020). Borsa İstanbul ve kripto paralar arasında saklı eşbütünleşme ilişkisi. Finans, Politik ve Ekonomik Yorumlar, 654, 119-137.

Sifat, I. M., Mohamad, A., and Shariff, M. S. B. M. (2019). Lead-lag relationship between Bitcoin and Ethereum: evidence from hourly and daily data. Research in International Business and Finance, 50, 306-321. doi: 10.1016/j.ribaf.2019.06.012

Şahin, E. E. (2020). Kripto para fiyatlarında balon varlığının tespiti: Bitcoin, IOTA ve Ripple örneği. Selçuk Üniversitesi Sosyal Bilimler Dergisi, 43, 62-69.

Urquhart, A. and Hudson, R. (2013). Efficient of adaptive markets? Evidence from major stock markets using vey long historic data. International Review of Financial Analysis, 28, 130142. doi: $10.1016 /$ j.irfa.2013.03.005

Urquhart, A. and McGroarty, F. (2016). Are stock markets really efficient) evidence of the adaptive market hypothesis. International Review of Financial Analysis, 47, 39-49. doi: 10.1016/j.irfa.2016.06.011

Vidal-Tomás, D., and Ibañes, A. (2018). Semi-strong efficiency of Bitcoin. Finance Research Letters, 27, 259-265. doi: 10.1016/j.fr1.2018.03.013

Yarovaya, L., Matkovskyy, R., and Jalan, A. (2020). The effects of a 'Black Swan' even (COVID-19) on herding behavior in cryptocurrency markets: evidence from cryptocurrency USD, EUR, JPY and KRW markets. Retrieved from: https://papers.ssrn.com/sol3/ papers.cfm?abstract_id=3586511

Yousaf, I., and Ali, S. (2020). Discovering interlinkages between major cryptocurrencies using high-frequency data: new evidence from COVID-19 pandemic. Financial Innovation, 6(45), 1-18.

Zhang, W., Wang, P., Li, X., and Shen, D. (2018). Quantifying the cross-correlations between online searches and Bitcoin market. Physica A: Statistical Mechanics and its Applications, 509, 657-672. doi: 10.1016/j.physa.2018.06.073 


\section{GENIŞLETILMIŞ ÖZET}

Mevcut çalışma COVID-19 salgını sürecinde dijital varlıklar ile ilgili alanın balonlaşma eğilimine maruz kalıp kalmadığını araştırmaktadır. Bu doğrultuda geleneksel Artırılmış Dickey-Fuller (Augmented Dickey Fuller-ADF) testi üzerinden Phillips vd. (2011) tarafından geliştirilen Eküs ADF (Supremum ADF-SADF) ve Phillips vd. (2015) tarafından oluşturulan Genelleştirilmiş Eküs ADF (Generalized Supremum ADF-GSADF) testlerinden yararlanarak sirasiyla serilerde tek balon ve çoklu balon oluşumunun ortaya çıkış tarihleri ve sıklıkları dikkate alınarak beş farklı kripto para biriminin - Bitcoin (BTC), Ethereum (ETH), Ripple (XRP), Stellar (XLM) ve Tether (USDT) Ocak 2, 2020 ve Ocak 2, 2021 dönemini kapsayan pandemi sürecinde balonlaşma eğilimi gösterip göstermediği analiz edilmektedir. Bu yöntemlerin ayırt edici özelliği ortaya çıkış ve bitiş tarihlerine göre potansiyel balonlaşma süreçlerinin belirlenebilmesidir. Özellikle GSADF yöntemi çerçevesinde finansal balonların başlangıcında varlık fiyatlarının patlayıcı bir davranış sergilediği yaklaşımı konunun bütünlüğü açısından büyük önem arz etmektedir. Bunun yanı sıra, belirtilen beş farklı kripto para biriminin seçimindeki temel çıkış noktası ise her birinin talep yönlü etkiler durumunda yüksek düzeyde oynaklık sergilemesi ve dolayısıyla fiyatlarında diğer kripto para birimlerine göre yüksek bir artış göstermesidir.

Çalışmanın ilgili literatüre katkısı ise iki açıdan oluşmaktadır. İlk olarak, Phillips ve diğerleri (2011) ve Phillips ve diğerleri (2015) tarafından gelisstirilen ve sırasıyla SADF ve GSADF testlerini kapsayan sağ kuyruk birim kök yöntemleri seçili dijital varlıklarda pandemi sürecindeki balonlaşma eğiliminin tespiti için kullanılmaktadır. Bu yöntemlerin kullanılmasının başlıca nedeni yakın geçmişte ortaya konan çalışmalar içerisinde finansal varlıklardaki fiyat değişimlerini ve dalgalanmalarını açıklamak için çoğunlukla balon davranışını kapsayan tekniklerin analiz kısmında göz ardı edilmesidir. Ancak COVID-19 salgını sürecinde bu tür varlıklardaki balonlaşma eğiliminin finans alanında önde gelen olgulardan birini oluşturduğu belirlenen varlıkların fiyatlarındaki değişimler vasıtasıyla rahatlıkla görülebilmektedir. Bu nedenle mevcut çalışma finansal balonları araştırmak ve hangi dönemlerde yoğunlaştı̆ıııı tespit etmek için yukarıda belirtilen sağ kuyruk birim kök testlerinden yararlanarak seçili kripto para birimlerinde oluşabilecek sorunları tartışmaktadır. Öte yandan bu makalenin ilgili literatüre ikinci önemli katkısı, balonlaşma davranışının çoğunlukla COVID-19 salgını gibi yoğun ekonomik gerileme dönemlerinde ortaya çıkabileceğini vurgulamaktır. Balon oluşumuna yönelik davranış kalıplarının ana nedenlerinden biri olarak üretimin yavaşlaması ve dolayısıyla firmaların kâr oranlarında ortaya çıkan azalmalar gösterilebilir. Ekonomik gerileme dönemlerinde toplam gelir miktarı daraldığından yatırımcıların çoğu finansal varlıklara yönelik alımları artırmaktadır. Sonuç olarak, bu dönemlerde varlık fiyatları gerçek/optimum değerlerinden uzaklaşarak balonlaşmaya yönelik davranış biçimleri sergileyebilmektedir.

Elde edilen analiz sonuçları Tether (USDT) dişında diğer tüm seçili kripto para birimlerinin COVID-19 sürecinde Ocak 2, 2020 ile Ocak 2, 2021 dönemi için balonlaşma dinamiğine sahip olduğunu göstermektedir. Tether (USDT)'in balonlaşma eğiliminin mevcut olmamasına ait en önemli nedenlerden biri olarak dolara sabitlenmesi vurgulanabilir. Bu çerçevede, balonlaşma eğilimini ortaya koyan ampirik çıktılar mevcut literatürdeki balonlaşma eğilimini rasyonellik kavramı altında değerlendiren ana akım yaklaşım ile çelişmektedir. Dolayısıyla Bitcoin (BTC), Ethereum (ETH), Ripple (XRP) ve Stellar (XLM)'ın fiyat değişimlerini açıklamaya katkıda bulunabilecek nedenlerin ve etkenlerin araştırılması için daha ileri çalışmaların yapılmasına kapı aralanmaktadır. Dünya sistemi için küresel pandemi koşulları göz önüne alındığında, uygulanan karantina süreçleri, artan işsizlik oranları, endüstriyel üretim seviyesinin düşmesi ve Ponzi tipi 
finans yoluyla artan oranlı spekülatif davranış eğilimleri benzeri ekonomik olgular dijital varlıkların fiyat davranışlarını önemli ölçüde etkilemekte ve farklılaştırmaktadır. Bu nedenle ilgili başlık altında daha derin analizler yapabilmek için farklı yöntemlere kapı aralanmasına ihtiyaç duyulmalıdır. Özellikle mevcut çalışmanın kullandığı teknikler çerçevesinde elde edilen bulguları genişletmek için Genelleştirilmiş Otoregresif Koşullu Değişen Varyans (Generalized Autoregressive Conditional Heteroskedasticity-GARCH) modeli ve/veya dalgacık analizleri (Wavelet Analysis) gibi diğer yöntemlerden faydalanabilmesi belirtilebilir. 